\title{
Prevalence of pathogenic yeasts and humoral antibodies to candida in diabetic patients
}

\author{
F. C. ODDS ${ }^{1}$, E. G. V. EVANS, M. A. R. TAYLOR, AND J. K. WALES \\ From the Mycology Unit, University Departments of Microbiology and Dermatology and the University \\ Department of Medicine, the General Infirmary at Leeds LS1 3EX, UK
}

SUMMARY The prevalence of oral yeasts and humoral precipitating antibodies to candida was estimated in 204 unselected diabetic patients (172 outpatients and 32 inpatients). Yeasts, mainly Candida albicans, were isolated from the mouths of $41 \%$ of the outpatients and precipitins were found in $17.5 \%$ although none of the patients had clinically overt candidiasis. The extent of oral yeast colonisation and incidence of antibodies was not related to their antidiabetic treatment or to the duration of their diabetes. It was, however, related to the blood glucose and urine sugar levels at the time they were sampled, the highest incidence being among the diabetic inpatients with high blood glucose levels at the time of sampling and the lowest among outpatients with normal blood glucose levels at the time of sampling. There was no such correlation when diabetic control over the previous 12-month period was considered.

The frequent occurrence of candida infections in patients with diabetes mellitus has been recognised for many years (Plass et al., 1931; Hopkins, 1932; Akrawi, 1960; Winner and Hurley, 1964; Hesseltine, 1965). The predisposing effect of diabetes has been confirmed by animal experiments (Andriole and Hasenclever, 1962; Hurley, 1966; Louria, et al., 1966; Van Cutsem and Thienpont, 1971) in which an induced diabetic state was associated with increased susceptibility to infection by pathogenic Candida species. Previous studies had shown the prevalence of yeasts to be greater among diabetics than among normal subjects (Sonck and Somersalo, 1963; Barlow and Chattaway, 1969), although this has not been the finding of all workers (Peters et al., 1966). The disparity in results may of course, be due to differences in sampling techniques, sites sampled, and selection of subjects. The aim of this study was to try to correlate the extent of yeast colonisation in diabetic patients with their degree of diabetic control, their antidiabetic treatment, and the duration of their clinical diabetic state. Precipitating antibodies to candida were also measured as an adjunct to cultural procedures because these antibodies can reflect the presence of a commensal yeast flora (Evans and Forster, 1976).

${ }^{1}$ Present address: Department of Microbiology, University of Leicester, Leicester LE1 7RH

Received for publication 15 February 1978

\section{Patients and methods}

\section{PATIENTS}

A total of 204 diabetic patients volunteered to participate in the survey. One hundred and seventy-two were unselected patients attending the Diabetic Clinic of the General Infirmary at Leeds, of whom 20 were untreated, newly diagnosed, diabetic patients principally with maturity onset diabetes. Thirty-two inpatients were studied; 20 were admitted to hospital because of ketoacidosis of varying severity; six patients were admitted for stabilisation of newly diagnosed diabetes on insulin therapy, and two patients were admitted with severe hypoglycaemia. Four patients were admitted for reasons unrelated to their diabetic control. Only one-third of these inpatients were assessed as having had poor diabetic control during the preceding year. None of the patients studied had clinically overt candidiasis.

ASSESSMENT OF DIABETIC CONTROL

A scoring system was used to assess diabetic control, which depended on the degree of glycosuria in a fasting urine specimen and the blood glucose level taken approximately two hours after breakfast. A score of 0-10 was given for the blood glucose, with one point increment for each $\mathrm{mmol} / \mathrm{l}$ rise in blood glucose above $6 \mathrm{mmol} / \mathrm{l}$ with a maximum of 10 for $>15 \mathrm{mmol} / \mathrm{l}$. A score of $0-5$ was given for glycosuria as assessed by Clinitest. Thus a patient with 
no glycosuria and a normal blood glucose level produced a score of 0 whereas a patient with $2 \%$ glycosuria and blood glucose of $>15 \mathrm{mmol} / \mathrm{l} \mathrm{had} \mathrm{a}$ maximum score of 15 . This diabetic score applied to the day the culture and blood samples were taken. For the purpose of the study a score for overall control during the 12 months preceding the sampling date was produced by calculating the mean of the scores for each clinic attendance in the previous year (approximately three visits for each patient). On an arbitrary basis a total mean score of $0-5$ was designated as good control, 6-10 moderate control, and 11-15 poor control.

\section{CULTURE TECHNIQUE}

The prevalence of yeasts in the mouth was estimated by a mouthwash technique. The mouth was selected as a sampling site since previous studies have nearly always revealed a higher incidence of yeasts in the oral cavity than at any other site (Mackenzie, 1961), and the mouthwash technique was chosen because it gives a better recovery of yeasts than mouth swabs (Somerville, 1964; McKendrick et al., 1967; Berdon and Seita, 1971; Schmitt, 1971). Patients were instructed to suck $5 \mathrm{ml}$ of sterile distilled water through a sterile drinking straw, to rinse the water around their mouths without gargling, and to expel the mouthwash into a sterile container through the straw; $0.1 \mathrm{ml}$ of each mouthwash was spread on to a Petri dish of Sabouraud's dextrose agar containing chloramphenicol $(50 \mathrm{mg} / \mathrm{l})$. The cultures were then incubated at $37^{\circ} \mathrm{C}$ for 48 hours, at which time any yeast colonies were counted. All yeasts were identified using standard procedures (Taschdjian et al., 1960; Lodder, 1970).

DETECTION OF PRECIPITATING ANTIBODIES Patients' sera were tested for the presence of precipitins to cytoplasmic antigenic extracts of Candida albicans and $C$. parapsilosis by double diffusion in agar using methods described previously (Odds et al., 1975).

\section{ANALYSIS OF RESULTS}

Patients were divided into groups according to the duration of their diabetes, their antidiabetic treatment, their diabetic score at the time of sampling, and their overall diabetic control for the previous 12 months. The proportion of patients from whom yeasts were isolated in each group, regardless of the quantity of yeasts recovered, was compared by determination of $\chi^{2}$ for pairs of groups in a fourfold table. The numbers of yeast colonies obtained in each group were compared by the Mann-Whitney U test. The incidence of precipitins in each group was compared in terms of proportion of positive reactors by the $\chi^{2}$ test. In all cases, results were regarded as significant when the probability that a given value of $\chi^{2}$ or $\mathrm{U}$ was obtained by chance was less than 0.05 .

\section{Results}

Yeasts were isolated from the mouths of $67(41 \cdot 4 \%)$ of the 162 diabetic outpatients sampled by culture. The most frequently isolated yeast was $C$. albicans $(60 \%)$; the remaining isolates comprised the pathogenic species $C$. tropicalis, C. krusei, C. guilliermondii, $C$. parapsilosis, Torulopsis candida, $T$. glabrata, and the saprophytic species Sacchoromyces cerevisiae and Cryptococcus laurentii.

Precipitating antibodies to cytoplasmic extracts of $C$. albicans were detected in $30(18 \%)$ of the 165 diabetic outpatients sampled serologically; $13(8 \%)$ reacted similarly to $C$. parapsilosis extract. The proportions of patients from whom yeasts were isolated, the quantity of yeast isolated, and the number of patients with antibodies to candida were not influenced by the treatment they were receiving (Table 1), and were no different in newly diagnosed untreated diabetic patients. Neither were the results influenced by the duration of the patient's diabetes. However, significant differences in the carriage of yeasts and the presence of yeast antibodies were seen when the patients were subdivided on the basis of their blood glucose and urine sugar levels at the time they were sampled mycologically (Table 2). Both the proportion of patients with positive yeast cultures $(69 \%)$ and the quantities of yeast recovered were significantly higher among the inpatient diabetics (the majority of whom had an acute disturbance of diabetic control) compared to the moderately ( $\mathrm{P}<$ $0.05)$ and poorly ( $P<0.01)$ controlled outpatients; the recovery of yeasts was lowest in the well controlled outpatients. The proportion of inpatients with positive yeast cultures and the quantities of yeast recovered fell within a few days with the control of hyperglycaemia (Table 3). There was also a higher prevalence of antibodies to candida among the poorly controlled diabetic outpatients compared with the moderately and well controlled diabetics. The proportion of well controlled diabetics with precipitins to $C$. albicans was significantly lower $(P<0.02)$ than the proportion of poorly controlled diabetics. At the time of admission diabetic inpatients had a lower incidence of yeast antibodies than the poorly controlled outpatients, but the incidence rose during the second week of hospitalisation.

When patients were grouped according to their overall diabetic control for the year before sampling, there was no significant difference in the carriage of 
Table 1 Isolation of oral yeasts and serum precipitin antibodies to yeasts in diabetic outpatients, grouped according to their antidiabetic therapy

\begin{tabular}{|c|c|c|c|c|c|c|c|}
\hline \multirow[t]{3}{*}{ Patient group } & \multirow{3}{*}{$\begin{array}{l}\text { No. of } \\
\text { patients }\end{array}$} & \multicolumn{3}{|c|}{ Yeast isolations } & \multicolumn{3}{|l|}{ Serology } \\
\hline & & \multirow[t]{2}{*}{$\begin{array}{l}\text { Number } \\
\text { sampled }\end{array}$} & \multirow[t]{2}{*}{$\begin{array}{l}\text { Number (\%) } \\
\text { with positive } \\
\text { isolations }\end{array}$} & \multirow{2}{*}{$\begin{array}{l}\text { Geometric } \\
\text { mean of colony } \\
\text { counts per } \\
0 \cdot 1 \mathrm{ml} \text { mouth } \\
\text { wash }\end{array}$} & \multirow[t]{2}{*}{$\begin{array}{l}\text { Number } \\
\text { sampled }\end{array}$} & \multicolumn{2}{|c|}{$\begin{array}{l}\text { Number (\%) with positive } \\
\text { precipitins to cytoplasmic } \\
\text { antigens }\end{array}$} \\
\hline & & & & & & C. albicans & C. parapsilosis \\
\hline $\begin{array}{l}\text { Newly diagnosed } \\
\text { (no treatment) }\end{array}$ & 20 & 13 & $4(31)$ & $1 \cdot 4$ & 19 & $6(32)$ & $1(5)$ \\
\hline $\begin{array}{l}\text { Diet alone } \\
\text { Diet +oral treatment } \\
\text { Diet }+ \text { insulin }\end{array}$ & $\begin{array}{l}12 \\
56 \\
84\end{array}$ & $\begin{array}{l}11 \\
55 \\
83\end{array}$ & $\begin{array}{r}5(45) \\
22(40) \\
36(43)\end{array}$ & $\begin{array}{l}1 \cdot 3 \\
2 \cdot 0 \\
2 \cdot 1\end{array}$ & $\begin{array}{l}11 \\
52 \\
83\end{array}$ & $\begin{array}{l}2(18) \\
10(19) \\
12(14)\end{array}$ & $\begin{array}{l}1(9) \\
7(13) \\
4(5)\end{array}$ \\
\hline
\end{tabular}

Table 2 Isolation of oral yeasts and serum precipitin antibodies to yeasts in diabetic patients, grouped according to the blood glucose and urine sugar at the time of sampling

\begin{tabular}{|c|c|c|c|c|c|c|c|}
\hline \multirow[t]{3}{*}{ Patient group } & \multirow{3}{*}{$\begin{array}{l}\text { No. of } \\
\text { patients }\end{array}$} & \multicolumn{3}{|c|}{ Yeast isolations } & \multicolumn{3}{|l|}{ Serology } \\
\hline & & \multirow[t]{2}{*}{$\begin{array}{l}\text { Number } \\
\text { sampled }\end{array}$} & \multirow[t]{2}{*}{$\begin{array}{l}\text { Number }(\%) \\
\text { with positive } \\
\text { isolations }\end{array}$} & \multirow{2}{*}{$\begin{array}{l}\text { Geometric } \\
\text { mean of colony } \\
\text { counts per } \\
0.1 \mathrm{ml} \text { mouth } \\
\text { wash }\end{array}$} & \multirow[t]{2}{*}{$\begin{array}{l}\text { Number } \\
\text { sampled }\end{array}$} & \multicolumn{2}{|c|}{$\begin{array}{l}\text { Number }(\%) \text { with positive } \\
\text { precipitins to cytoplasmic } \\
\text { antigens }\end{array}$} \\
\hline & & & & & & C. albicans & C. parapsilosis \\
\hline $\begin{array}{l}\text { Inpatients } \\
\text { Outpatients }\end{array}$ & 32 & 32 & $22(69)$ & $8 \cdot 2$ & 29 & $4(14)$ & $4(14)$ \\
\hline $\begin{array}{l}\text { with poor control } \\
\text { with moderate control } \\
\text { with good control }\end{array}$ & $\begin{array}{l}44 \\
50 \\
76\end{array}$ & $\begin{array}{l}42 \\
47 \\
75\end{array}$ & $\begin{array}{l}21(50) \\
20(43) \\
27(36)\end{array}$ & $\begin{array}{l}3 \cdot 7 \\
2 \cdot 0 \\
1 \cdot 3\end{array}$ & $\begin{array}{l}43 \\
48 \\
72\end{array}$ & $\begin{array}{r}13(30) \\
8(17) \\
8(11)\end{array}$ & $\begin{array}{l}5(12) \\
4(9) \\
4(6)\end{array}$ \\
\hline
\end{tabular}

Table 3 Isolation of oral yeasts and serum precipitin antibodies to Candida albicans grouped according to the number of days after admission

\begin{tabular}{|c|c|c|c|c|c|c|}
\hline \multirow{3}{*}{$\begin{array}{l}\text { Day after } \\
\text { admission }\end{array}$} & \multicolumn{3}{|c|}{ Yeast isolations } & \multicolumn{3}{|l|}{ Serology } \\
\hline & \multirow[t]{2}{*}{$\begin{array}{l}\text { Number } \\
\text { sampled }\end{array}$} & \multirow[t]{2}{*}{$\begin{array}{l}\text { Positive (\%) } \\
\text { isolation }\end{array}$} & \multirow{2}{*}{$\begin{array}{l}\text { Geometric mean } \\
\text { of colony counts } \\
\text { per } 0 \cdot 1 \text { ml mouth } \\
\text { wash }\end{array}$} & \multirow[t]{2}{*}{$\begin{array}{l}\text { Number } \\
\text { sampled }\end{array}$} & \multicolumn{2}{|c|}{$\begin{array}{l}\text { Number }(\%) \text { with positive precipitins } \\
\text { to cytoplasmic antigens }\end{array}$} \\
\hline & & & & & C. albicans & C. parapsilosis \\
\hline $\begin{array}{l}1 \\
4-6 \\
9-11\end{array}$ & $\begin{array}{l}32 \\
24 \\
15\end{array}$ & $\begin{array}{l}69 \\
54 \\
40\end{array}$ & $\begin{array}{l}5 \cdot 5 \\
1 \cdot 2 \\
0.5\end{array}$ & $\frac{30}{13}$ & $\begin{array}{l}4(13) \\
\overline{4(31)}\end{array}$ & $\frac{4(13)}{1(8)}$ \\
\hline
\end{tabular}

yeasts or prevalence of yeast antibodies between the poorly or moderately controlled diabetic outpatients (Table 4). However, the prevalence of antibodies to C. albicans among the well controlled diabetic outpatients was significantly lower $(P<0.05)$ than for the other groups.

\section{Discussion}

The mucous membranes of the body are commonly colonised by yeasts. The total number of yeasts present is thought to be important to the development of infection as it has recently been suggested that, in order to change from a commensal to a pathogenic mode of life, yeasts need to aggregate in large numbers to accumulate sufficient enzymes for penetration of mucous membranes and epidermis (Wain et al., 1976). Also passage of yeasts from the small intestine into the blood stream by a persorption mechanism is currently thought to be an important route of entry for systemic yeast infection (Stone et al., 1974; Evans, 1975), and large numbers of yeasts are thought to be necessary for this mechanism to operate also (Stone et al., 1973).

The predisposition of diabetic patients to infection by pathogenic Candida species has been explained in terms of enhancement of yeast growth by elevated tissue fluid glucose levels (Knight and 
Table 4 Isolation of oral yeasts and serum precipitin antibodies to yeasts in diabetic patients, grouped according to control of diabetes over the 12 months before sampling

\begin{tabular}{|c|c|c|c|c|c|c|c|}
\hline \multirow[t]{3}{*}{ Group (overall control) } & \multirow{3}{*}{$\begin{array}{l}\text { Number in } \\
\text { Group }\end{array}$} & \multicolumn{3}{|c|}{ Yeast isolations } & \multicolumn{3}{|l|}{ Serology } \\
\hline & & \multirow[t]{2}{*}{$\begin{array}{l}\text { Number } \\
\text { sampled }\end{array}$} & \multirow[t]{2}{*}{$\begin{array}{l}\text { Number } \\
\text { positive (\%) }\end{array}$} & \multirow{2}{*}{$\begin{array}{l}\text { Geometric } \\
\text { mean of colony } \\
\text { counts per } \\
0.1 \mathrm{ml} \text { mouth } \\
\text { wash }\end{array}$} & \multirow[t]{2}{*}{$\begin{array}{l}\text { Number } \\
\text { sampled }\end{array}$} & \multicolumn{2}{|c|}{$\begin{array}{l}\text { Number }(\%) \text { with positive } \\
\text { precipitins to cytoplasmic } \\
\text { antigens }\end{array}$} \\
\hline & & & & & & C. albicans & C. parapsilosis \\
\hline $\begin{array}{l}\text { Poor } \\
\text { Moderate } \\
\text { Good }\end{array}$ & $\begin{array}{l}32 \\
65 \\
54\end{array}$ & $\begin{array}{l}31 \\
54 \\
53\end{array}$ & $\begin{array}{l}15(48) \\
26(41) \\
21(40)\end{array}$ & $\begin{array}{l}2 \cdot 9 \\
1 \cdot 7 \\
1 \cdot 7\end{array}$ & $\begin{array}{l}30 \\
64 \\
51\end{array}$ & $\begin{aligned} 6 & (20) \\
13 & (20) \\
4 & (8)\end{aligned}$ & $\begin{array}{l}2(7) \\
5(8) \\
3(6)\end{array}$ \\
\hline
\end{tabular}

Fletcher, 1971). Thus one would expect that there should be a correlation between diabetic control at any one time and the extent of yeast colonisation of these membrane sites commonly inhabited by yeasts. In the diabetic patients studied, only the level of blood glucose and urine sugar at the time of sampling was found to correlate with the recovery of yeasts from the mouth. The present study also suggests that the degree of colonisation of the mouth by yeasts may be quickly and directly altered by blood glucose levels. This is supported by the fact that the patients admitted to hospital had high oral yeast colony counts (in samples collected within 24 hours of admission), which rapidly fell within a few days as their hyperglycaemia was controlled. This response is in contrast to that of nondiabetic inpatients, who often acquire a high incidence of yeasts during their stay in hospital (Stone et al., 1973).

Previously, the presence of antibodies to cytoplasmic antigens of candida was held to be diagnostic for systemic forms of candidiasis. However, these antibodies have recently been shown to occur in the absence of overt systemic infection, for example, in pregnant women and in patients undergoing openheart surgery (Murray et al., 1969; Stanley et al., 1972; Evans and Forster, 1976).

In the diabetic outpatients the distribution of precipitating antibodies to the cytoplasmic antigens among the patient groups was similar to the distribution of yeasts in the patient groups. Antibodies were detected significantly more often in diabetic patients with high blood glucose and urine sugar levels at the time of sampling. This reinforces the view that these antibodies are formed as a transient response to levels of commensal yeasts that are high enough to permit persorption of yeast cells or passage of soluble yeast antigens across the gut wall (Evans and Forster, 1976). The relatively low incidence of antibodies among the hospitalised diabetic patients at the time of admission is probably due to a time lag between the build-up of yeasts at times of severe hyperglycaemia and subsequent antibody formation. This is supported by the rising incidence of candida antibodies during hospitalisation.

The lack of correlation of yeast numbers and antibody levels with long-term diabetic control may arise from the difficulty in assessing such control except in an arbitrary way such as is used here. Further, in many diabetic patients the degree of hyperglycaemia fluctuates from day to day, and the changes in the quantity of oral yeasts and antibodies may in turn be transitory.

The results of this study suggest that during episodes of severe hyperglycaemia there is an increase in the quantities of yeasts in the digestive tract and that an increased antibody response follows this event. They also lend further weight to the supposition that poorly controlled diabetics are more at risk of yeast infection than others (Sonck and Somersalo, 1963; Knight and Fletcher, 1971). Finally, the transient nature both of the yeast overgrowth and of the antibody response should be borne in mind when diabetic patients are investigated for suspected systemic yeast infection.

We are grateful to Mrs J. O'Malley for technical help, to Mr R. A. Forster for his assistance, and to the Leeds Area Health Authority (Teaching) for financial support.

\section{References}

Akrawi, Y.Y.(1960). The biology of intestinal moniliasis. Journal of the Faculty of Medicine, Baghdad, 2, 63-69. Andriole, V. T., and Hasenclever, H. F. (1962). Factors influencing experimental candidiasis in mice. I. Alloxan diabetes. Yale Journal of Biology and Medicine, 35, 96-112.

Barlow, A. J. E., and Chattaway, F. W. (1969). Observations on the carriage of Candida albicans in man. British Journal of Dermatology, 81, 103-106.

Berdon, J. K., and Seita, C. L. (1971). The incidence of Candida albicans in hospital patients. Journal of Oral Medicine, 26, 123-126. 
Evans, E. G. V. (1975). The incidence of pathogenic yeasts among open-heart surgery patients-the value of prophylaxis. Journal of Thoracic and Cardiovascular Surgery, 70, 466-470.

Evans, E. G. V., and Forster, R. A. (1976). Antibodies to Candida after operations on the heart. Journal of Medical Microbiology, 9, 303-308.

Hesseltine, H. C. (1965). Vulvitis: due to mycosis, atrophy and avitaminosis. American Practitioner and Digest of Treatment, 6, 864-867.

Hopkins, J. G. (1932). Moniliasis and moniliids. Archives of Dermatology and Syphilology, 25, 599-614.

Hurley, R. (1966). Experimental infection with Candida albicans in modified hosts. Journal of Pathology and Bacteriology, 92, 57-67.

Knight, L., and Fletcher, J. (1971). Growth of Candida albicans in saliva; stimulation by glucose associated with antibiotics, corticosteroids and diabetes mellitus. Journal of Infectious Diseases, 123, 371-377.

Lodder, J. (1970), The Yeasts. North-Holland, Amsterdam.

Louria, D. B., Busé, M., Brayton, R. G., and Finkel, G. (1966).The pathogenesis of Candida tropicalis infections in mice. Sabouraudia, 5, 14-25.

McKendrick, A. J. W., Wilson, M. I., and Main, D. M. G. (1967). Oral Candida and long term tetracycline therapy. Archives of Oral Biology, 12, 281-290.

Mackenzie, D. W. R. (1961). Yeasts from human sources. Sabouraudia, 1, 8-15.

Murray, I. G., Buckley, H. R., and Turner, G. C. (1969). Serological evidence of Candida infection after openheart surgery. Journal of Medical Microbiology, 2, 463-469.

Odds, F. C., Evans, E. G. V., and Holland, K. T. (1975). Detection of Candida precipitins. A comparison of double diffusion and counter immunoelectrophoresis. Journal of Immunological Methods, 7, 211-218.

Peters, R. B., Bahn, A. N., and Barens, G. (1966). Candida albicans in the oral cavities of diabetics. Journal of Dental Research, 45, 771-777.
Plass, E. D., Hesseltine, H. C., and Borts, I. H. (1931). Monilia vulvovaginitis. American Journal of Obstetrics and Gynaecology, 21, 320-334.

Schmitt, J. A. (1971). Epidemiological investigations of oral Candida albicans. Mycopathologia et Mycologia Applicata, 43, 65-87.

Somerville, D. A. (1964). Candida albicans in a maternity hospital. New Zealand Medical Journal, 63, 592-596.

Sonck, C. E., and Somersalo, O. (1963). The yeast flora of the anogenital region in diabetic girls. Archives of Dermatology, 88, 846-852.

Stanley, V. C., Hurley, R., and Carroll, C. J. (1972). Distribution and significance of Candida precipitins in sera from pregnant women. Journal of Medical Microbiology, 5, 313-320.

Stone, H. H., Geheber, C. E., Kolb, L. D., and Kitchens, W. R. (1973). Alimentary tract colonization by Candida albicans. Journal of Surgical Research, 14, 273-276.

Stone, H. H., Kolb, L. D., Currie, C. A., Geheber, C. E., and Cuzzell, J. Z. (1974). Candida sepsis: pathogenesis and principles of treatment. Annals of Surgery, 179, 697-711.

Taschdjian, C. L., Burchall, J. J., and Kozinn, P. J. (1960). Rapid identification of Candida albicans by filamentation on serum and serum substitutes. American Journal of Diseases of Children, 99, 212-215.

Van Cutsem, J., and Thienpont, D. (1971). Experimental cutaneous Candida albicans infection in guinea pigs. Sabouraudia, 9, 17-20.

Wain, W. H., Price, M, F, and Cawson, R. A. (1976). Factors affecting plaque formation by Candida albicans infecting chick chorio-allantoic membrane. Sabouraudia, 14, 149-154.

Winner, H. I., and Hurley, R. (1964). Candida Albicans. Churchill, London.

Requests for reprints to: Dr F. G. V. Evans, Mycology Unit, The General Infirmary, Leeds LS1 3EX. 